\title{
El mejor pastor descalzo, san Pascual Baylón o la incursión teatral de Ginés Campillo de Bayle
}

\section{El mejor pastor descalro, san Pascual Baylón or the theatrical incursion of Ginés Campillo de Bayle}

\author{
RAMÓN DOMÉNECH VILLA \\ phonascus67@gmail.com \\ Universitat d'Alacant
}

\begin{abstract}
Resumen: Cuando los últimos decenios del siglo XVII iban marcando el final de la Casa de Austria en España, un clérigo nacido en Elche (Alicante), Ginés Campillo de Bayle, intentó su incursión en el mundo literario de la época. Su figura y obra, por un motivo u otro, siempre han estado rodeadas por un entorno de misterio, desgraciada fortuna y escasa estimación. Valorado con precaución por unos pocos, ignorado o criticado por la mayoría, gran parte de su producción lírica, narrativa y teatral ha conseguido llegar, a pesar de todo, a nuestras manos. Un ejemplo de lo señalado es la comedia teatral, así titulada por el propio autor, El mejor pastor descalzo, san Pascual Baylón; toda una demostración de un subgénero característico del Siglo de Oro, que nuestro escritor publica durante los últimos coletazos de tan simbólico período. Las siguientes líneas quieren mostrar un breve análisis de la citada obra, señalando sus características más significativas e identificando cuáles serían las influencias y fuentes de las que el autor ilicitano se surte, sin olvidar las particularidades literarias del que llegó a ser beneficiado de la iglesia parroquial de Santa María la Mayor de su ciudad natal.
\end{abstract}

Palabras clave: comedia de santos, Campillo de Bayle, teatro, Siglo de Oro, Elche, San Pascual Baylón

\begin{abstract}
During the last decades of the seventeenth century, which marked the end of the Royal House of Austria in Spain, a cleric born in Elche (Alicante), Ginés Campillo de Bayle, tried to participate in the literary world of the time. His life and work, for one reason or another, have always been linked to mystery, misfortune and low esteem. Valued cautiously by few, ignored or criticized by most, we have now in our hands, a part of his lyrical, narrative and theatrical productions. An example of a characteristic sugnere of Golden Century is , El mejor pastor descalzo, san Pascual Baylón, that our writer published during the last gasps of this symbolic period. The following article tries to be a brief analysis of that work, delving into its most significant features, and identifying what influences and sources the author would used, without forgetting the literary peculiarities which benefited from the parish church of Santa Maria Mayor of his hometown.
\end{abstract}

Keywords: comedy saints, Campillo de Bayle, theater, Golden Century, Elche, saint Pascual Baylón 
Ramón Doménech Villa. El mejor pastor descalzo, san Pascual Baylón o la incursión teatral de

Ginés Campillo de Bayle

\section{Introducción}

Durante el transcurso del año 1691, la imprenta del librero Vicente Cabrera, situada en la ciudad de Valencia, publicó la obra de teatro del clérigo ilicitano Ginés Campillo de Bayle († 1711) titulada El mejor pastor descalzo, san Pascual Baylón. El ambiente teatral de la ciudad, que contó con una gran tradición durante el siglo XVII, debió ayudar a que arraigara en el licenciado y escritor el interés por este tipo de representaciones. Estamos seguros que esta afición se iniciaría desde aquellas sillas reservadas para el clero que se encontraban en el afamado "Corral de la Olivera» de la capital, con la asistencia a las diferentes obras que allí tenían lugar. Un espectáculo y espacio el teatral que, a pesar del debate referente a las prohibiciones específicas de la iglesia, unido al tira y afloja relativo su idoneidad y uso con fines didácticos, contaba con la presencia de capellanes, párrocos y beneficiados, junto a otros personajes pertenecientes al alto clero de la localidad y de los municipios limítrofes a esta (Mouyen 1991).

De una manera u otra, está claro que el clérigo ilicitano quiso plasmar sus intereses y preferencias teatrales, resultantes de la correspondiente y particular recepción literaria, tanto en los capítulos de su novela Gustos y disgustos del Lentiscar de Cartagena ${ }^{1}$, como en su comedia hagiográfica que nos disponemos a analizar.

Sería un año después de la canonización del fraile franciscano san Pascual $^{2}$, y tras casi ochenta de la publicación de la que fue considerada la primera «comedia de santos» escrita por Lope de Vega, El santo negro Rosambuco de la ciudad de Palermo — que vio la luz en 1612 dentro de la Tercera parte de las comedias de Lope de Vega y otros autores (Alonso 1972; Vega 2008)_, cuando la única obra teatral de Campillo de Bayle, recibida y reconocida hasta la fecha, salía a la calle.

La citada creación literaria de Lope nos servirá para señalar un antes y un después en el particular ámbito de las obras teatrales centradas en la figura de los santos (Vega 2008), relacionando una serie de hechos bastante significativos; una situación que nos ayudará a contextualizar la producción resultante y a comprobar su importancia:

a) El Arte nuevo de hacer comedias en este tiempo, de Lope de Vega, fue leído en 1609 (Arellano \& Mata 2011).

b) Las últimas comedias de santos de Lope de Vega aparecieron en el volumen de la Veinticuatro parte perfecta, durante el año 1641. Estas fueron: San Nicolás de Tolentino y Barlán y Josafá (Alonso 1972).

c) La comedia El santo negro Rosambuco de la ciudad de Palermo debió de ser escrita antes de 1607, con toda probabilidad en 1604, según lo indicado por Morley \& Bruerton (1968: 393) y Giuliani (2002: 402), citados por Vega (2008: 22).

1 Con una primera impresión en la ciudad de Valencia en el año 1689 y una segunda en el 1691.

2 Pascual Baylón Yubero (Torrehermosa, Zaragoza, 16 de mayo de 1540, Vila-real, Castellón, 17 de mayo de 1592). Fue beatificado por el papa Paulo V el 19 de octubre de 1618 y canonizado por Alejandro VIII el 16 de octubre de 1690 (AA. VV. 2005). 
d) Según las aportaciones de Morley \& Bruerton (1968: 264-265), y citado por Vega (2008: 22), Lope de Vega ya había escrito otra comedia de contenido hagiográfico y con un protagonista de raza negra; se trata de El negro del mejor amo, Antíobo de Cerdeña. La probable fecha para la datación de esta obra se encontraría entre 1599 y 1603.

e) A pesar de las críticas realizadas por parte de Miguel de Cervantes en Don Quijote (I, 48), relativas a las denominadas por el alcalaíno «las comedias divinas» (Courdec, 2008: 69), podemos afirmar que él mismo escribió una de estas entre 1605 y 1615, dentro de la colección Ocho comedias y ocho entremeses nuevos nunca representados (1615), bajo el título El rufián dichoso (Sirera 1999).

Durante el tiempo que transcurre entre la publicación de El santo negro Rosambuco (1612) y la impresión de la comedia de Campillo de Bayle, la producción literaria de comedias hagiográficas auriseculares puede considerarse como activa y extremadamente significativa. Prueba de ello es el importante número de obras escritas y publicadas por autores de la talla y renombre de Tirso de Molina, Calderón, Pérez de Montalbán, Rojas Zorrilla, Agustín Moreto o Juan Bautista Diamante (Vega 2008).

En este contexto, tras la publicación de la primera propuesta de dramaturgia lopística de santos relacionada con el Arte Nuevo, y aproximadamente un año después de la única creación en esta línea por parte de Miguel de Cervantes, la ciudad de Valencia vive una explosión desde diferentes perspectivas: religiosas, históricas y literarias. Este particular escenario, junto a los antecedentes literarios descritos en el párrafo anterior, tuvo en Campillo una repercusión temática y estilística, a pesar del tiempo transcurrido entes las diferentes fechas indicadas.

Esta situación contaba con una serie de antecedentes que podemos subrayar. Así, por un lado, podemos referirnos a la publicación de tres significativas obras, directamente relacionadas con el género y ámbito aquí tratado. Todas ellas dentro del ámbito de esta línea dramática, e incluidas en el segundo volumen colectivo, dedicado a dramaturgos valencianos (Sirera 1999; Vega 2008), que lleva por título Norte de la poesía española. Ilustrado del sol de doce comedias (que forman segunda parte) de laureados poetas valencianos, $y$ de doce escogidas loas y otras rimas a varios sujetos (1616):

a) La fundación de la Orden de Nuestra Señora de la Merced por el rey don Jaime, de Francisco Tárrega (1554-1602).

b) El gran patriarca don Juan de Ribera, arzobispo de Valencia, de Gaspar Aguilar (1561-1623).

c) La gran comedia del triunfante martirio y gloriosa muerte de San Vicente, hijo de Huesca y patrón de Valencia, de Ricardo de Turia ${ }^{3}$ (1578-1638).

\footnotetext{
3 Según los datos aportados por Barrera (1860: 678-679), sería el pseudónimo de Pedro Juan de Rejaule y Toledo, jurisperito y autor del Apologético de las comedias españolas (1616), una obra que contiene obras del citado Ricardo Turia y de Gaspar Aguilar.
} 
Por otra parte, es interesante señalar que la ciudad de Valencia, en 1608, fue protagonista de los más importantes fastos que tuvieron lugar con motivo de la beatificación de san Luis Bertrán ${ }^{4}$, otro significativo santo del País Valenciano. A las celebraciones y actos desarrollados durante varios días, junto a todo tipo de galas y ceremonias que sirvieron como demostración de la fe y la alegría que reinaban en la ciudad, acompañó la publicación de la obra Vida y muerte del santo fray Luis Bertrán, que también tuvo por autor a Gaspar de Aguilar (Ferrer 1999).

Fuera con el nombre de «comedias de divinas apariencias», «comedias de cuerpo», «comedias a lo divino», «comedias de aparato», «comedias de cosas sagradas» o «comedias de historia santa» (Cazés 2015), lo que parece estar claro es que, cuando a finales de 1690 es canonizado san Pascual Baylón — hecho que motiva a Campillo a escribir su creación dramática—, el subgénero hagiográfico dramático todavía tiene una gran aceptación entre el público y entre los escritores de la época, aunque puedan existir diferentes líneas de interpretación y creación. Esta situación, junto a los diversos contextos de recepción literaria del clérigo ilicitano, facilitaría la asimilación de los diferentes esquemas, estructuras y rasgos significativos, unido todo ello a la «hibridez y heterogeneidad de la comedia hagiográfica» (Cazés, 2015: 48).

El caso es que, motivado por un encargo procedente de la orden franciscana, siguiendo instrucciones de otras instancias civiles o religiosas, situaciones habituales en estos entornos de festividades conmemorativas (Grazia 2008; Cazés 2015), o simplemente por el interés personal de participar en las distintas celebraciones que se realizaron con motivo de la canonización del santo ${ }^{5}$ — sin olvidar la influencia que pudo ejercer la figura de su amigo Josef Miralles como «retor» de Montfort y de Agost ${ }^{6}$ - ; Ginés Campillo y Bayle escribe una dramatización sobre la vida de san Pascual Baylón, al estilo de las comedias hagiográficas del Siglo de Oro español, cuyo análisis nos servirá para comprobar toda una serie de detalles referentes a las características literarias y estilísticas del autor.

Dentro del ámbito de la existencia de referencias posteriores a su publicación, encontramos distintas menciones en obras de carácter recopilatorio, enciclopédico y ensayístico; si bien es cierto que en ninguna de ellas se realiza ningún tipo de estudio de mayor profundidad. Un ejemplo es el caso que encontramos en Barrera (1860: 61), cuando se refiere a la comedia a la hora de realizar la

4 Valencia 1526-1581. Curiosamente, san Luis Bertrán fue beatificado por Paulo V en 1608 y canonizado en 1691 por el papa Clemente X (Galduf, 1961); lo que significa que pasaron más de ochenta años desde el significativo título de Aguilar, hasta la verdadera canonización.

5 Como es el caso de la colección lírica de 1691 relacionada con Guillén de Rocafull, conde de Albatera, y su participación en un festejo taurino, con motivo de la canonización de san Pascual —Poesías escritas por algunos ingenios valencianos, al acierto conque toreó en las fiestas que se hizieron en Valencia a la canonización de san Pascual Baylón, el día 28 de mayo de 1691...-; en las mismas fechas también se puede señalar la de Cielos de fiesta, musas de Pascua en fiestas reales que a san Pascual coronan sin más fines y cordialísimos devotos..., ambas recopilaciones festivas citadas por Mas (1996: 293). Otro ejemplo es el de la publicación realizada por Cortés (1693), donde recoge justas, fiestas y academias celebradas, por el mismo motivo, en el municipio de Almansa.

6 Cuyo nombre aparece en los preliminares de Campillo (1689 y 1691) y en la obras miscelánea Sacro Monte Parnaso de las musas católicas de los reinos de España (Ramón 1687). 
correspondiente relación de las obras de Campillo. Un caso similar lo encontramos en Salvá \& Mallén (1872: 380), al señalarnos que «parece existe una comedia de Campillo impresa en 1691, intitulada El mejorpastor descalzo, San Pascual Bailón». Ibarra (1895: 311), sin citar directamente el título de la obra, nos indica que Ginés Campillo «dejó varios libros, en especial comedias». De carácter general es también la referencia que encontramos en Cejador (1916), donde solo se recoge el título de la obra. Desde una curiosa perspectiva, motivada por el tipo de información, se sitúa la reseña de Martí (1927: 65), donde, además de los datos ya conocidos, se puede leer: «En cuartos de 50 páginas a dos columnas. Tiene esta comedia tres jornadas. (Librería de M. Berenguer, de Valencia)». Durante la lectura del curioso y significativo ensayo de Snavely (1927), se pueden leer las siguientes consideraciones, no siempre correctas tras las últimas aportaciones realizadas:

Nothing seems to be known about the comedy El mejor pastor descal々o, San Pascual Bailón. San Pascual Bailón is an authentic saint who entered the convent of Menores de Albatesa, of the barefooted order of Saint Francis, in Valencia, in 1564, and who was canonized by Pope Alexander VIII in 1690 (pp. 2-3).

Es posible encontrar otra cita a la obra en Simón (1967: 357) donde aparece catalogada con el número 3780, dentro de la entrada correspondiente a Ginés Campillo y a su obra novelística, teatral y poética. En el diccionario dedicado a personajes de la provincia de Alicante, publicado por Calatayud (1977: 53), aparece otra referencia superficial a la comedia de Campillo: «Y en aquel mismo año ${ }^{7}$ fue cuando escribió y publicó la comedia titulada El mejor pastor descalžo, San Pascual Bailón, que también fue muy celebrada». Un caso singular es el que se encuentra en Simini (1999: 117), este autor, aunque no estudia directamente la obra teatral de Campillo de Bayle, hace mención a ella en el ámbito de las composiciones literarias compuestas con motivo de la canonización de san Pascual Baylón. En concreto, su presencia se produce cuando se refiere al estudio del trabajo de Fajardo y Acevedo, referido en Cortés (1693), y a la existencia de una creación teatral, en la misma línea temática que la comedia escrita por el clérigo ilicitano: «Ma esiste un'altra comedia — coeva_ su san Pasquale Baylon: Ginés Campillo de Bayle, El mejor pastor descalzo, San Pasqual Baylon, Valencia, Vicente Cabrera, 1691 (esemplare: BNMT 4398)».

\section{Análisis de la comedia El mejor pastor descalzo, san Pascual Baylón}

\subsection{Información inicial y jornada primera}

La lectura inicial de la obra de Campillo (1691a) nos muestra a un escritor influenciado por las corrientes dramáticas de consumo de su época, ligadas a las propuestas de renovación presentadas por Félix Lope de Vega, a través de su Arte nuevo (Arellano \& Mata, 2011). Ambas situaciones, sin duda, se producen por medio de la particular interpretación y recepción realizada a raíz de las lecturas del clérigo y la visualización de las representaciones dramáticas de la época.

\footnotetext{
7 Hace referencia a 1691.
} 
La división de tres jornadas, junto a la estructura y organización general de la obra, nos hace suponer una trama que, a priori, respondería al esquema tradicional de: planteamiento, nudo y desenlace.

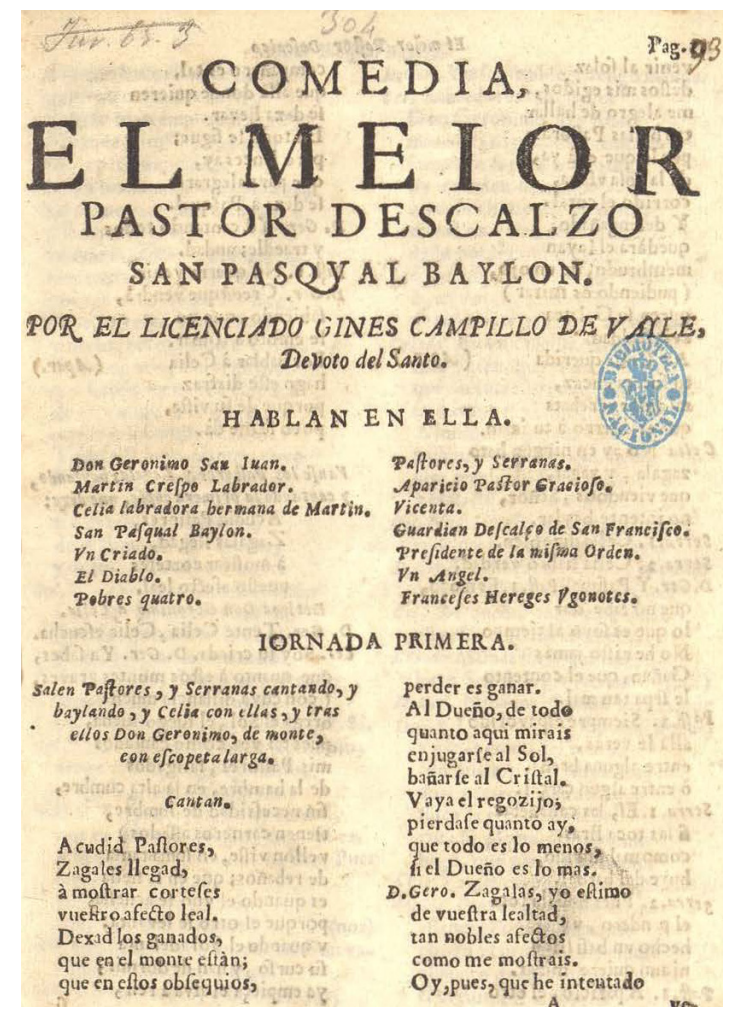

Ilustración 1. Primera página de El mejor pastor descalzo, san Pascual Baylón.

La primera página sirve para ponernos en contacto con la nómina de personajes que desfilarán por la representación teatral: «hablan en ella», dirá el autor para presentar esta relación al lector. Un tema este, el relativo a la participación de los diferentes arquetipos de participantes, que ha sido extensamente debatido dentro del ámbito de los estudios dedicados a la comedia de santos (Sirera 1999; Martínez 2008; Cazés 2015). Una cuestión que no puede separarse de la relativa al origen y procedencia social de los actores que, encima de tablas y escenarios, interpretaban a tan característico repertorio, excesivamente simbólico para un tipo de representación de temática tan significativa (Aparicio 1990; Herzig 2008; Martínez 2008). De esta manera, dentro del ámbito de los participantes, es posible establecer dos grupos; el que agrupa a los personajes colectivos: pastores, serranas, franceses herejes y hugonotes, y pobres; y el de los protagonistas individuales, que pueden separarse según su participación en las diferentes tramas. A esto hay que añadir dos perfiles de personajes característicos en el ámbito de las comedias de santos: el del gracioso — que esta vez aparece bajo el nombre de Aparicio—, participación que sirve para establecer un nuevo vínculo respecto a la propuesta estilística de Lope - y el del diablo. Esta relación de variado repertorio podría aumentarse con aquellos que participan en lo que podría denominarse la «corte celestial», con su presencia grupal o de carácter individual. 
Dentro de la obra de Campillo de Bayle, nada más comenzar su lectura, identificamos dos líneas argumentales, que convergerán en una trama única durante las páginas finales:

a) La profana; que incluye los temas del gusto de las representaciones teatrales del Siglo de Oro: amor, honor y tradición, adaptados a cada uno de los diferentes estamentos sociales.

b) La religiosa; fundamental para la clasificación de la obra dentro del grupo de la comedia de santos. Una línea donde participa san Pascual a través de su protagonismo en diferentes escenas, junto a la descripción de distintas fases de su vida. Esta trama, en numerosos momentos de la obra, cede el protagonismo a la profana, debido a la ausencia de acción y el inmovilismo manifiesto durante gran parte de la obra.

La jornada primera nos mostrará las pretensiones de don Gerónimo — noble del lugar- hacia el personaje encarnado por la campesina Celia, y el posterior enfrentamiento con Alonso Crespo, padre de esta, motivado por la tradicional y particular defensa del honor. Esta situación finaliza con la muerte del lugareño a manos del noble, unido al «secuestro» de Celia por parte de Gerónimo, y su traslado a la ciudad de Valencia.

Será en la siguiente escena donde, por primera vez, contemplaremos la aparición de san Pascual. El santo hará su presentación rodeado del colectivo de pastores y serranas que cantan y bailan a su alrededor, intentándolo hacer partícipe del alegre ambiente. La primera intervención del santo, ante la actitud festiva del grupo, no puede ser más ilustrativa respecto a su carácter, además de incluir una de las muchas suertes de redondillas ${ }^{8}$, con versos octosílabos y heptasílabos, que nos encontramos a lo largo de toda la lectura de la obra:

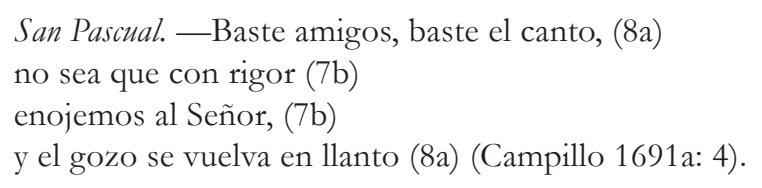

Esta actitud manifestada, no quita para que pueda existir un toque de humor por parte de los pastores participantes:

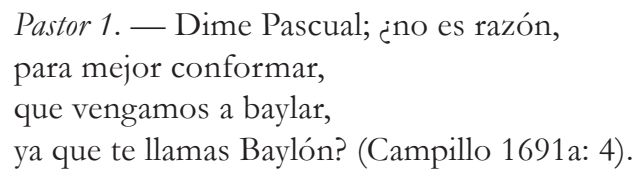

\footnotetext{
8 Que el dominio de la composición lírica y la métrica no es uno de los fuertes de Campillo queda de manifiesto en esta comedia. Es cierto que Lope habla sobre el uso de la redondilla para los diálogos dentro de su Arte nuevo de hacer comedias en este tiempo (Lope de Vega 2006), aunque el escritor ilicitano, en algunos momentos de la obra, muestra cierta relajación por este aspecto.
} 
Los personajes, uno tras otro, van realizando su aparición. Sobre Aparicio recaerá el protagonismo de estos momentos; figura que simboliza al tradicional gracioso del teatro de la época. Él, durante una extensa intervención, será el encargado de describir lo sucedido con anterioridad en el marco de la trama profana. La alternancia entre santo y gracioso da lugar a un curioso diálogo, utilizando para ello un tono familiar para el lector de este tipo de obras. Esta situación desemboca con la aparición de Martín Crespo, hermano de Celia, quien busca venganza por la muerte de su padre. Ese es el momento elegido por Campillo para introducir los primeros datos biográficos del santo. El diálogo entre Aparicio y Martín será utilizado para informarnos sobre la correspondiente localización: el municipio de Torrehermosa, en la provincia de Zaragoza, lugar que vio nacer al protagonista:

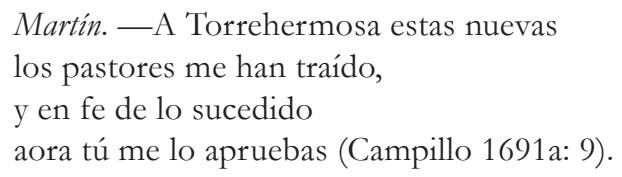

Martín, a cambio de cien ducados, llega a un acuerdo con Aparicio para que sea él quien lleve a cabo la deseada venganza. Para que se produzca el hecho violento, le entrega un arma. En ese momento san Pascual aparece, y se produce la primera referencia a la figura del diablo. El santo detecta nerviosismo en la actitud de Aparicio, consigue que este le cuente la verdad y le hace arrojar la pistola.

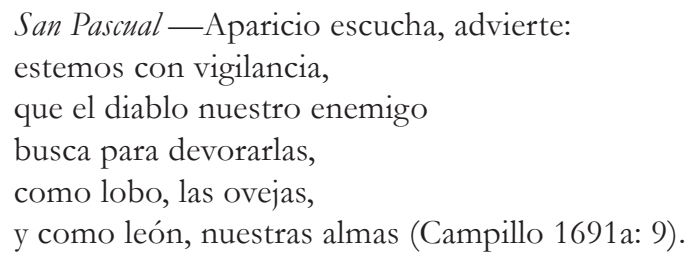

Campillo, aunque no estemos ante una comedia enfocada a la narración de un martirio o similar, parece que no quiere dejar de lado este aspecto, así se lo hace saber al lector, cuando describe el atuendo del santo: «Traerá Pascual a la cintura dos géneros de cordeles, unos en forma de disciplinas, y otros a modo de Rosario» (Campillo 1691a: 10). El autor elegirá este momento de la comedia para introducir el primer milagro atribuido históricamente a san Pascual (Salmerón, 1858): el santo consigue que mane agua de una piedra, tras un golpe del bastón que trae consigo: «Abaja la cara Aparicio, y el santo da un golpe con el cayado, y sale un caño de agua, que baña a Aparicio » (Campillo 1691a: 11).

Sin duda, esta descripción de la escena es el elemento visual más complejo que ha aparecido hasta ahora en la obra ${ }^{9}$. La escenografía, su dificultad, su trascendencia como recurso para centrar la

9 Hasta aquí habíamos leído descripciones habituales: entradas, salidas y utilería que podríamos calificar como normal, 
atención el público, su papel como complemento indispensable, se ha convertido en un aspecto fundamental de las comedias de santos; bien como línea de estudio interno de cada obra dramática, como para la argumentación de características significativas, a la hora del reconocimiento y definición del subgénero hagiográfico como tal (Aparicio 1990; Sirera 1991; Ferrer 1999; Teulade 2008; Grazia 2008).

Campillo aprovecha este momento para que santo y gracioso dirijan sus pasos al reino de Valencia. Una situación que se produce desde la perspectiva reflexiva, metafórica y mística por parte de san Pascual, sin dejar de lado los comentarios chistosos que acompañan al personaje de Aparicio:

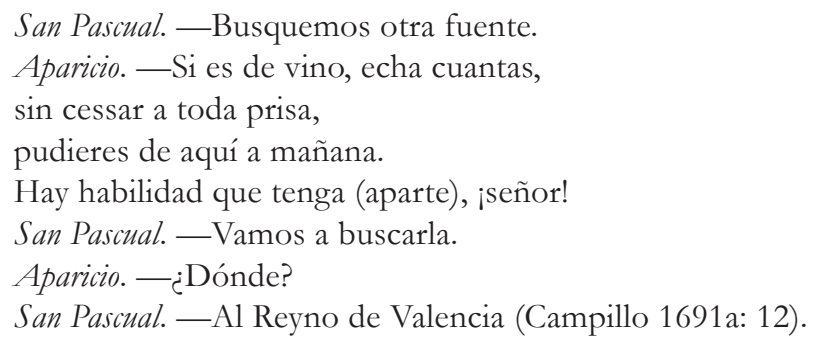

El inicio del viaje por parte de la pareja es utilizado por Campillo para presentarnos a un nuevo y singular personaje dentro de la trama profana. Se trata de Vicenta, la criada; quien nos informa de la llegada a Valencia de Gerónimo y Celia.

Las intervenciones del personaje de Aparicio son utilizadas por el escritor como hilo conductor entre las diferentes escenas, el escritor también lo convierte en uno de los narradores principales de la biografía de san Pascual. Un ejemplo de esta situación lo encontramos en los datos que se nos ofrecen aprovechando la descripción de un viaje un tanto caótico: lugar de nacimiento, trabajo como pastor, estancia en la ciudad de Elche, ingreso en la orden de los franciscanos o permanencia en el convento de Orito — pedanía del municipio de Montfort del Cid_-, donde se produjo el conocido como «Milagro de la aparición de la Eucaristía», en el que san Pascual tuvo la visión de Jesucristo, durante el desarrollo del sacramento correspondiente (Salmerón1858):

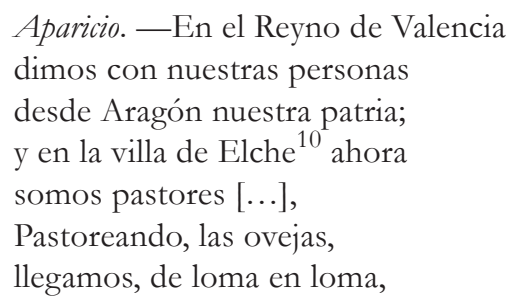

en un contexto dramático de estas características.

10 No debemos olvidar el origen de Ginés Campillo de Bayle. 


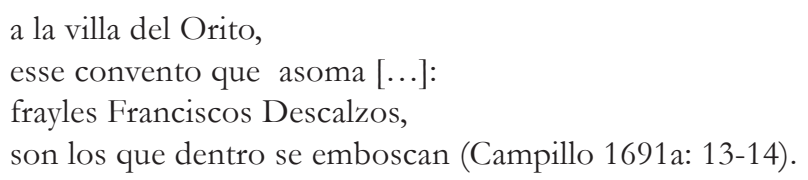

Las obligaciones religiosas no pueden olvidarse en una obra teatral de estas características. Ginés Campillo no olvida en ningún momento las funciones educadoras asignadas a las comedias de santos. Los objetivos propagandísticos forman parte del todo; algunas veces con mayor o menor acierto, otras siendo más obvios desde la perspectiva de la recepción del espectador y del lector (Aparicio 1990; Courdec 2008):

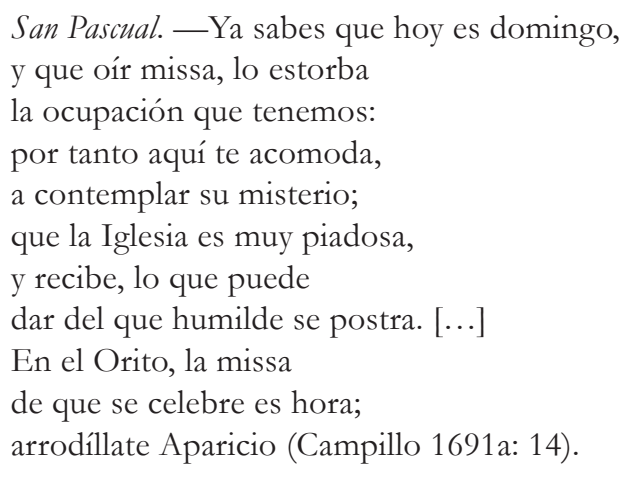

La cita al pueblo de Orito es aprovechada para incluir la referencia al citado milagro de la aparición de la Eucaristía. Al mismo tiempo, los elementos escenográficos van adquiriendo más complejidad y protagonismo: «Tocan dentro una campanilla, y por lo alto se aparece una estrella, que sobre el teatro va pasando, y cuando está en medio se abre, y descubre un cáliz y una ostia» (Campillo 1691a: 15).

Las continuas escenas y roces entre Aparicio y Pascual dan lugar a situaciones cómicas, donde el santo, a pesar de poner su particular toque de humor, no puede desprenderse su papel de censor y reprobador hacia aquellas acciones que no concuerdan con una rígida moral —o la de Campillo. Esta situación, al final de la primera jornada, da lugar a una serie de apariciones muy significativas que preparan el desenlace del primer tercio de la obra: «Hazen que se van, y sale por un escotillón el demonio con manto negro, cantando, que les detiene. [...] Aparece un ángel que corre la línea del teatro, cantando» (Campillo 1691a: 17).

Las tentaciones a la pareja, por parte del demonio, no están ausentes en este nuevo marco escenográfico. Las instigaciones relativas a los placeres terrenales, que intentan ser frenadas por el ángel correspondiente, son respondidas por san Pascual: 


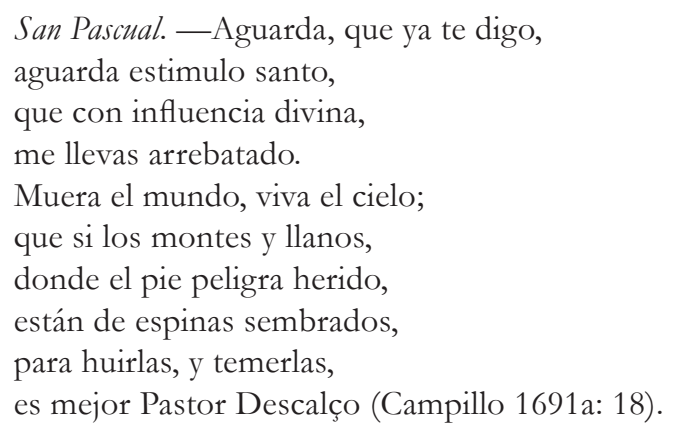

Ante esta situación, el demonio se retira derrotado de la escena, por primera vez:

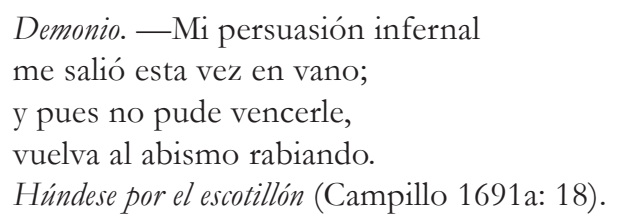

\subsection{Transcurso de la segunda jornada}

El giro que se producen en la obra, durante los inicios de la jornada segunda, no pasa desapercibido para el receptor. La sección que corresponde al «nudo», siguiendo los consejos que aparecen en el Arte nuevo, se inicia adjudicando un destacado protagonismo a la Orden Franciscana ${ }^{11}$; una situación que se refleja a través de la incorporación de nuevos personajes: guardián y presidente, quienes manifiestan sus particulares opiniones hacia el fraile:

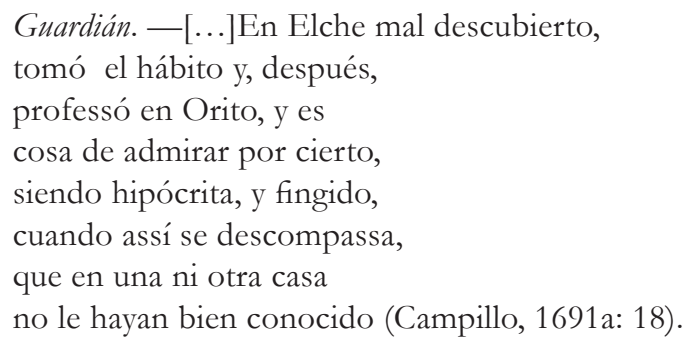

Campillo de Bayle, previendo la relajación del público al inicio de esta jornada, motivada por el cariz que toman los sucesos, no tiene más remedio que recurrir, siguiendo la tradición y estrategias

11 Con anterioridad ya se ha insistido sobre el papel que las comedias de santos cumplen desde esta perspectiva publicitaria. Además, a todo ello, hay que unir la frecuencia del encargo de este tipo de obras literarias. 
Ramón Doménech Villa. El mejor pastor descalzo, san Pascual Baylón o la incursión teatral de Ginés Campillo de Bayle

indicadas en líneas anteriores, al uso de medios escenográficos que ayuden a mantener la concentración de los receptores. El escritor acude a la participación de personajes ya conocidos, el demonio, Aparicio y el ángel, entre otros, como colaboradores activos y complementarios de los recursos que se desplegarán sobre la escena. Unas condiciones que influirían en el espectador, y que ilustran tres momentos muy significativos:

1) La cercanía al éxtasis por parte de san Pascual, con toda la parafernalia correspondiente.

2) El nuevo objetivo y plan diseñado por el demonio para tentar a san Pascual.

3) El momento de la penitencia y flagelación por parte del presidente de la Orden Franciscana.

Respecto la escenografía, señala Campillo (1691a: 19):

\footnotetext{
Llégase al otro lado el santo, donde avrá una puerta grande que se abre, y se descubre una cozina, lumbre y bancos alrededor, sentados en ellos los frayles que puedan, y el presidente el primero. [...]

Baxa un ángel cantando y, llegando al teatro, entra en la cozina, toma a Pascual de la mano, y lo va sacando afuera; y assidos al santo el presidente y Aparicio, como que le detienen y no le dexan salir. Todos tres salen como a la fuerça del ángel; y los otros que hazen frayles, dentro de la cozina se levantan en pie.
}

Las entornos que describen intentos de tentación, desde el terreno de lo carnal, son algo habitual en este tipo de representaciones. Además, como no podía ser menos, la aparición de una figura femenina suele ser recurrente:

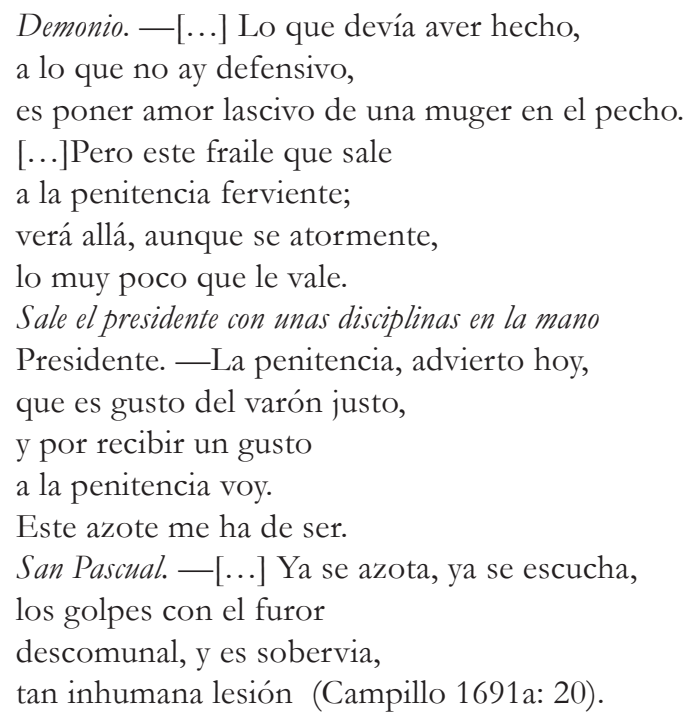


San Pascual no permanece ajeno a lo que sucede, algo que aprovecha para mantener sus particulares enfrentamientos con el demonio, sin olvidar la pertinente ambientación de la escena: «Sale el demonio huyendo, y el santo amagándole con el cordón. [...] Húndese por el escotillón y salen llamaradas» (Campillo 1691a: 20).

Para continuar con el esquema de la comedia, Campillo introduce un diálogo entre Vicenta y Celia, su objetivo es que el espectador conozca los sentimientos amorosos de la criada. Una situación que es aprovechada para que Celia nos dé una serie de datos sobre su estancia:

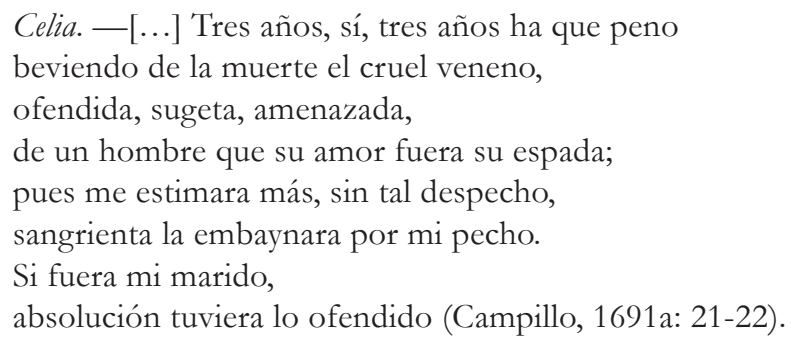

El mismo marco nos sirve para contemplar el retorno de Martín a la obra, donde informa a su hermana cuáles son sus intenciones.

Una vez finalizada esta situación, Campillo hace uso de otro grupo de personajes colectivos relacionados con la vida real y los milagros atribuidos a san Pascual. Nos referimos a un grupo de pobres, de los que Aparicio y el santo se encargan y preocupan por darle el oportuno alimento. La vuelta a la escena del guardián de la orden favorecerá un contexto que no es ajeno a obras y autores del Barroco: las referencias, de una manera no muy diplomática, a judíos y ramas familiares no compuestas por cristianos viejos:

San Pascual. - Aquí hay también su tozino.

$[\ldots]$

Pobre 1. - El tozino es de lo bueno que gusté en mi vida.

$[\ldots]$

Pobre 3. - Este es regio.

Pobre 4. - Es de sangre noble y limpio, aunque me digan que es puerco (Campillo, 1691a: 25).

Este es el contexto utilizado por el guardián para comunicar a Pascual y a Aparicio que deberán realizar un viaje a París, con la misión de llevar una documentación y cruzar los Pirineos. Se trata de un hecho real, basado en una de las labores que tuvo que realizar san Pascual, respecto a la cuestión teológica de la presencia de Cristo en la Eucaristía, frente al ataque de las ramas protestantes calvinistas francesas: los hugonotes. Esta realidad, unida a algún viaje narrado anteriormente, es útil como ejemplo de lo que Aparicio (1990) llama «nomadismo», a la hora de referirse a la definición del perfil del protagonista de la comedia de santos. Una línea de trabajo que se encuentra en un 
ámbito parecido al que señala Grazia (2008), cuando se refiere a los viajes en la comedia de santos, y ese peregrinar por Europa, donde no se pierde la perspectiva de los destinatarios.

La situación se muestra propicia para que el guardián realice una referencia a Melisenda de Jerusalén. ${ }^{12}$ El demonio y Vicenta vuelven a hacer presencia en escena. En esos momentos, llevada por los malos consejos de su acompañante procedente del averno, ella, fuera de sí, le declara a san Pascual su amor $^{13}$ en una situación donde violencia y ardor comparten protagonismo:

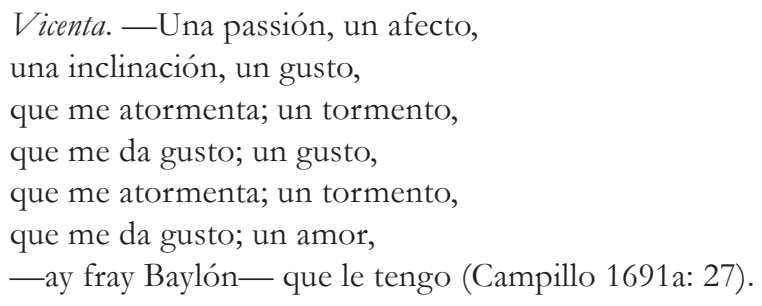

En una obra de estas características, dentro del contexto histórico en el que está elaborada, tampoco pueden faltar las referencias de carácter misógino, que se añaden al papel de la mujer, ya comentado en las diferentes escenas presenciadas:

San Pascual. -Cocodrillo del infierno, suelta sirena traydora, Dios me valga (Campillo 1691a: 27).

El retorno de Aparicio describe una nueva derrota del demonio y sus intenciones:

Demonio. -Mi lance pierdo. (Campillo 1691a: 27).

Las palabras del gracioso tampoco dejan bien parada a Vicenta. De nuevo, se observa el lugar de la mujer en este tipo de creaciones literarias:

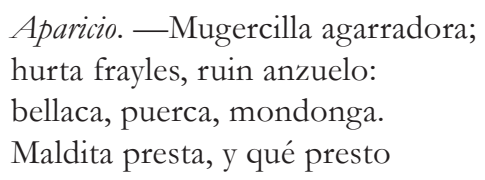

12 (1105 - 11 de septiembre de 1161). Reina de dichos santos lugares (AA. VV. 2005).

13 Es esta una cuestión común, sobre la que se insiste en diversos estudios del subgénero: la defensa de la castidad por parte del santo y el rechazo permanente a las relaciones amorosas, que adquieren forma de tentación (Sirera 1991; Teulade 2008). 
agarró del pobretillo,

para sacarle el dinero (Campillo 1691a: 28).

El demonio inicia su retirada del escenario, en el mismo momento que Vicenta pide perdón por su comportamiento irracional, aunque esto no libra a Aparicio de recibir un cachete por parte de la criada ante su frívolo comportamiento, que es utilizado por el escritor para enlazar con la siguiente escena de la jornada:

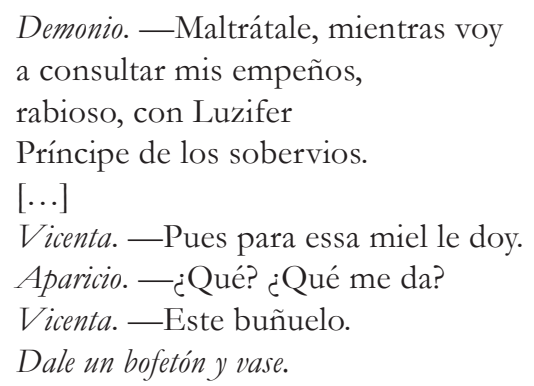

Las dos tramas — religiosa y profana-, cada vez a mayor velocidad, van convergiendo en una sola; lo que sirve como recurso para preparar nuevas situaciones dentro de la comedia. La presencia de don Gerónimo y san Pascual ayuda a conocer otro tipo de relaciones existentes en el pasado. En este contexto, la escenografía — dentro y fuera del espacio teatral tradicional — vuelve a jugar un papel fundamental en la búsqueda permanente de la atención:

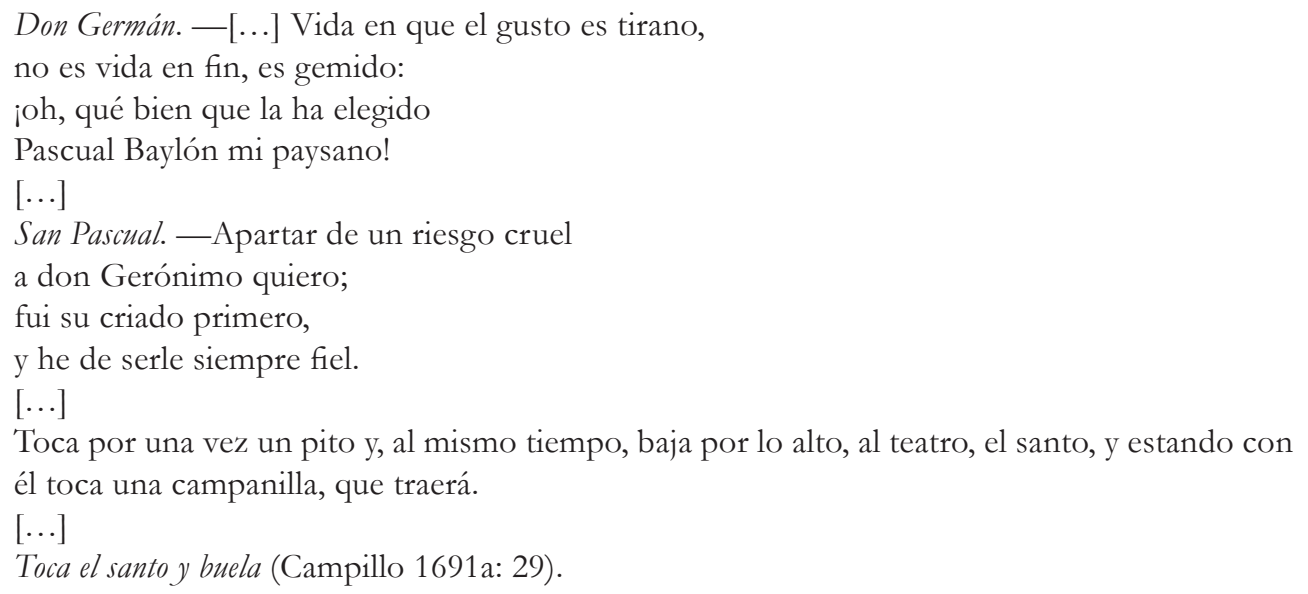

Celia y Martín retornan a las tablas. Este último, poseído por una mayor sed de venganza, reprocha a su hermana una supuesta complicidad en la muerte de su padre. La intervención de Vicenta resulta providencial para que Martín salga de la escena y no cumpla con su objetivo. Una extensa 
intervención de Celia, junto a las reflexiones de Vicenta, ofrece la posibilidad de mantener el hilo argumental, que desemboca en una decisión definitiva para la obra:

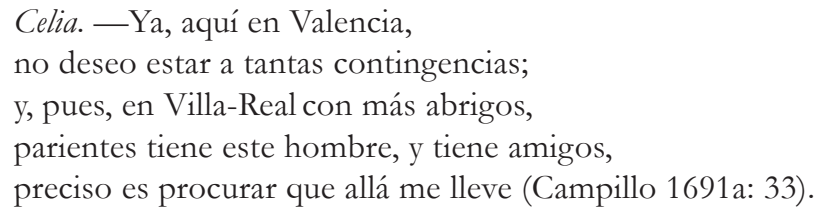

Mientras, el escritor prepara el final de la segunda jornada, para ello utiliza la justificación del señalado viaje a Francia por parte de santo y gracioso, así nos lo hace saber a través del vestuario de ambos: «Salen san Pascualy Aparicio con sombreros, báculos y alforjas para el camino» (Campillo, 1691a: 33).

El miedo y la ironía están presentes en el momento de la marcha. Aparicio continúa con su particular papel de narrador, y aprovecha para incluir alguna referencia histórica sobre hechos acaecidos en los Pirineos:

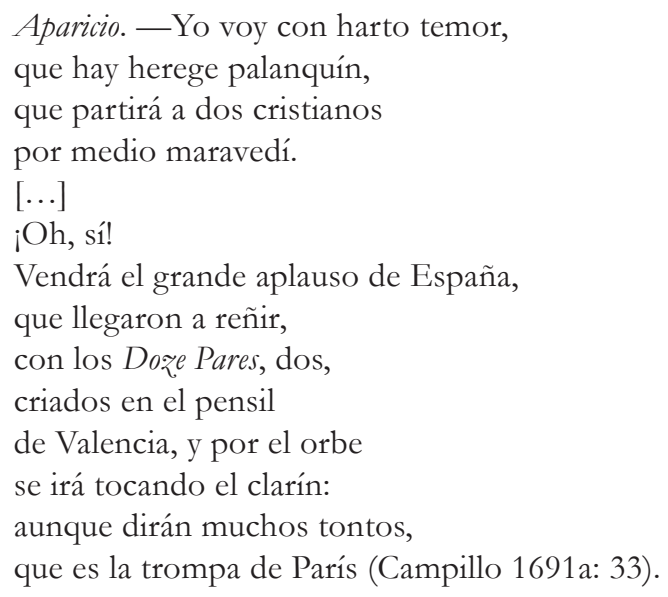

Campillo de Bayle, de nuevo, es consciente de la importancia y necesidad de la escenografía, que adquiere un especial protagonismo en el final de la escena. Sus indicaciones suponen un trabajo extra para tramoyistas y colaboradores: «Arrodillanse el santo y Aparicio, y passa por arriba un ángel, de una parte a otra, arrollidado al pie de una cruv, como que la tiene de pie y canta» (Campillo 1691a: 33).

La cruz, símbolo de la cristiandad, será entregada a los viajeros por el ángel, para que sea llevada a tierras francesas, además de servirles de seguro, frente a posibles ataques.

El escritor ilicitano prepara un intenso final de jornada, con referencias variadas a la simbología francesa y española, entre la fortaleza de una y la debilidad de la otra: 


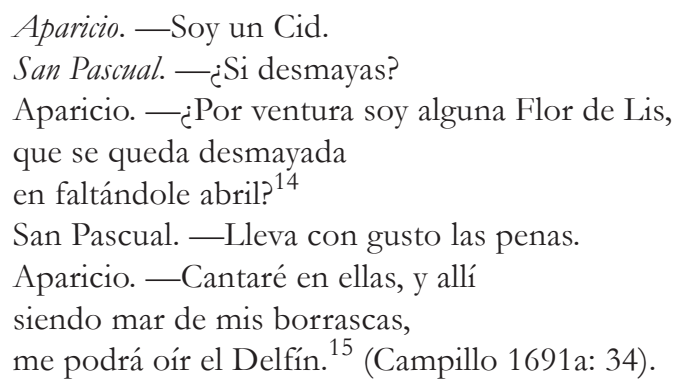

La contemporaneidad de la acción que se desarrolla en cada obra dramática, junto a la existencia de anacronismos de todo tipo y paradojas, unido a la descontextualización y la crítica sobre la licitud de las mismas, son elementos inherentes en las comedias hagiográficas, citados con frecuencia en las investigaciones desarrolladas (Sirera, 1991 y 1999; Martínez 2008; Teulade 2008). En relación con estos temas, Campillo, en el momento de concluir la segunda jornada, nos facilita un curioso dato, por medio de las palabras de Aparicio (Campillo 1691a: 34):
Y si allí a mi me encarcelan, será que querrá el rey Luis vengarse de la prisión del rey Francisco en Madrid.

Las líneas reproducidas despiertan un gran interés, pues nos ayudan a tener una visión relativa a la fidelidad de los datos facilitados al público durante el transcurso de la obra, y a la veracidad de la contextualización histórica: ${ }^{16}$

\begin{abstract}
El rey que estuvo en prisión, en la ciudad de Madrid, fue Francisco I de Francia (Coñac, -12 de septiembre de 1494-Rambouillet, 31 de marzo de 1547). Francisco I fue vencido y hecho prisionero en la Batalla de Pavía (1525), viéndose obligado a firmar el Tratado de Madrid (1526). Durante su cautiverio fue alojado en la Torre de los Lujones, en la Plaza de la Villa de Madrid.

A pesar del reinado de seis monarcas franceses durante la vida de san Pascual Baylón, el santo no coincidió con ninguno que ejerciera su mandato bajo el nombre de Luis.

El monarca que reinó en Francia, coincidiendo en el tiempo con Ginés Campillo, fue Luis XIV de Francia «el Rey Sol» (Saint-Germain en Laye, Francia, 5 de septiembre de 1638-Versalles, Francia, 1 de septiembre de 1715) (AA. VV. 2005).
\end{abstract}

14 Ironía y referencia a Francia y a su monarquía.

15 Título nobiliario francés empleado ininterrumpidamente desde 1349 hasta 1830, y reservado a los príncipes herederos al trono de Francia que fuesen hijos legítimos del monarca reinante (AA.VV., 2005).

16 No debemos olvidar que Pascual Baylón nació en 1540 y murió en 1592; y la muerte de Campillo se sitúa en 1711. 
Si atendemos a los datos indicados, comprobaremos la falta de rigor en el relato de Campillo, un hecho que se produce, con toda probabilidad, de forma consciente, con el objetivo de que el público se sitúe mejor en la escena, identificándose con el tiempo y el contexto, y participando del traslado previsto por parte de los dos personajes. El recurso que el autor utiliza consiste en situar al santo y a su acompañante de ruta, como contemporáneos suyos y del público receptor de la comedia, y no en el momento histórico que le correspondería, si observamos la biografía de san Pascual y la del ilicitano.

\subsection{Desenlace de la obra}

La jornada tercera se inicia con una simbólica persecución a nuestros viajeros protagonistas, una vez que se encuentran en territorio francés. Asuntos religiosos llevaron a san Pascual y a Aparicio a París, y cuestiones idénticas están a punto de arrebatarles la vida, al borde del martirio, a través de la lapidación, como si de los antiguos cristianos se tratara, por controversias de mandato superior y de fe:

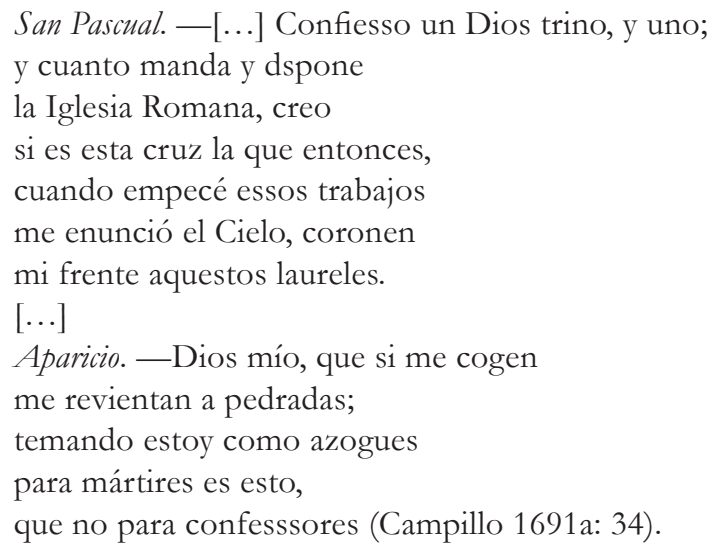

Un francés, que se compadece de ellos, ayuda a salvar sus vidas. La decisión es obvia: la vuelta a España de ambos.

Mientras, Celia, ya en Vila-real, avisa a don Gerónimo de las intenciones de su hermano. El diálogo entre los dos revela cuestiones pendientes, a la vez que tópicas en este tipo de comedias: amor, estatus social y honor siempre estarán presentes, de una manera u otra. En algunos momentos del diálogo, nos cuesta ver al Campillo clérigo tradicionalista, pues utiliza expresiones alejadas de su estilo sobrio, plano y alejado de contextos amatorios:

Celia. - $[\ldots]$ Don Gerónimo, señor, amante, ya que no esposo [...].

Don Germán. - Si yo olvidando mi punto, te doy de esposo la mano, 


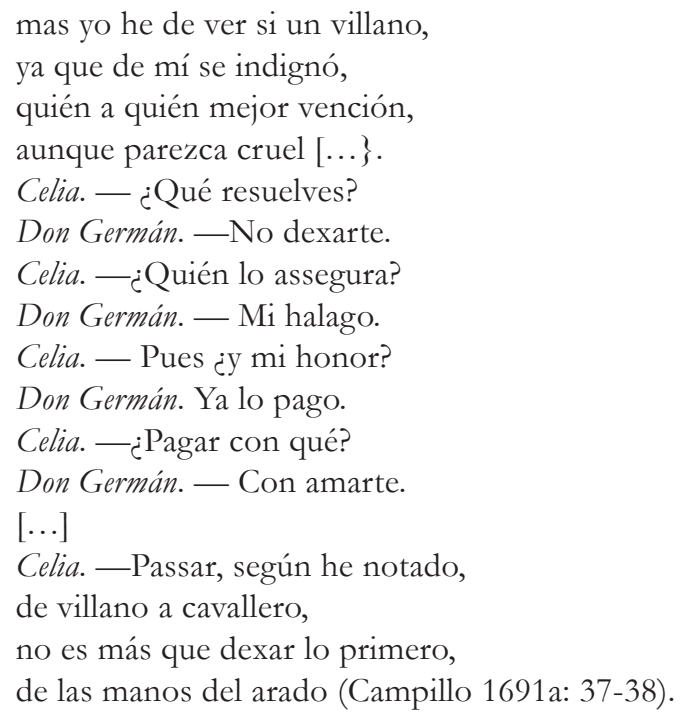

Durante el desarrollo de su particular ruta, Pascual y Aparicio llegan a Vila-real. De nuevo, Campillo recurre a la escenografía como medio para conseguir la atención del receptor. De esta manera, se pretende que este preste atención y capte la parte religiosa de la obra hagiográfica:

\footnotetext{
Passan todos a la otra parte, donde babrá una puerta grande, que Aparicio la abre y se descubre, dentro, un buerto, árboles a las paredes, y en cuadros de huertos tronchos de coles, verzas y lechugas; mondos y sin hojas, y el santo en medio con una azada, como que trabaja (Campillo 1691a: 38).
}

De los atribuidos a san Pascual (Salmerón 1858) en su vida real, un nuevo milagro es descrito aprovechando esta situación. Nos referimos a aquel donde el santo da de comer a los pobres que se agolpaban a la puerta del convento; para el receptor no puede pasar desapercibido el paralelismo con la multiplicación de los peces y panes:

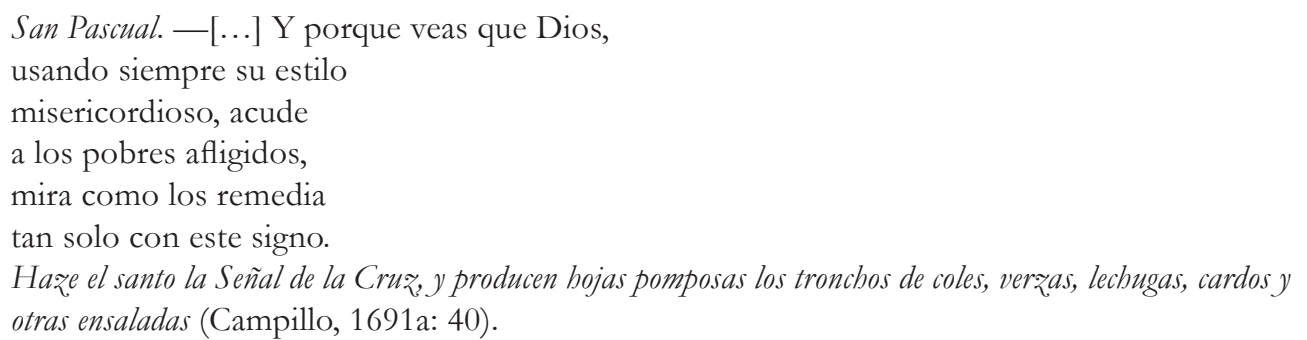

El escritor elige este momento, entre la admiración del público y la presencia de la seductora «maravilla» en escena (Courdec 2008), para preparar el desenlace de la obra. En esta significativa 
situación, Ginés Campillo pondrá sobre el escenario todos los elementos que el teatro pone a disposición de la compañía y del autor (Sirera 1999; Teulade 2008). La narración de la vida de san Pascual, en principio, no da para complejos argumentos finales: no hay conversión, no hay martirio, no hay escenas que, por una u otra causa, lleven fácilmente a la estupefacción del público. Por este motivo, el escritor describe la siguiente situación, bastante común en otras vidas santas de la época: «Vase el santo subiendo en éxtasis» (Campillo 1691a: 41).

Tras estos primeros instantes de recogimiento místico, la trama profana vuelve a las páginas de la comedia: Martín y Vicenta servirán de puente para el retorno de Pascual, junto al presidente y el guardián, y una intervención del gusto del subgénero y del escritor:

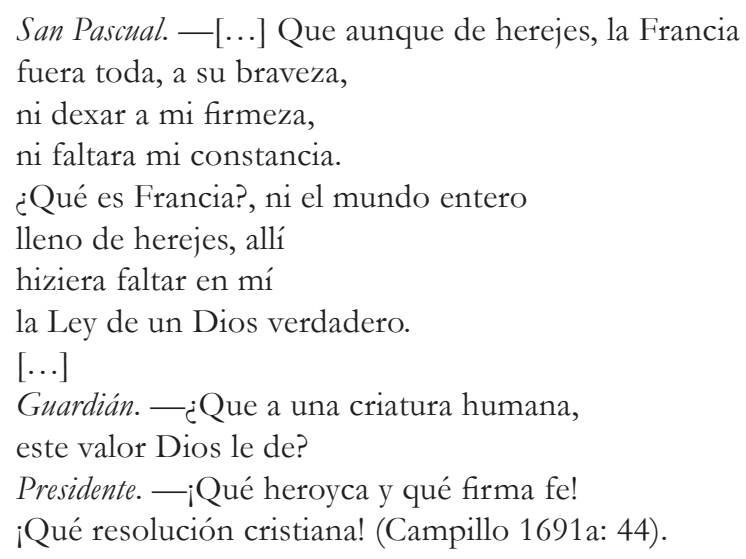

Todo parece decidido para el desenlace de la obra. Los personajes, como suele ser habitual, aparecen, uno tras otro, utilizando el argumento como excusa, cada uno cumpliendo con el rol encomendado: «Salen don Gerónimo con espada y daga desnuda; Martín con carpa y escopeta, y una en la mano, como amenazándole para tirarle; y el demonio tras ellos (Campillo 1691a: 44).

Una nueva aparición del diablo se produce sobre la escena, quien no ceja en sus intenciones. Mientras él solo desea que se produzca la tan deseada venganza, mejor para sus intereses si es mutua, los restantes personajes intentan convencer a Martín y a don Gerónimo para que cesen en su irreconciliable actitud. Nadie parece que pueda solucionar una situación abocada a la tragedia. Sin embargo, Pascual, participando en un particular milagro de la cosecha propia de Campillo, será quien se interponga entre el villano y el caballero, desbaratando las intenciones del singular demonio, que se pone en guardia ante el cariz de los sucesos:

Demonio. - Aquí es menester valerme

de cuantas astucias sepa (Campillo 1691a: 47). 
Gracias a la intervención del santo, el público asiste a una particular alternancia escenográfica, ligada al arbitraje del santo. El fin está cercano, y las consecuencias claras:

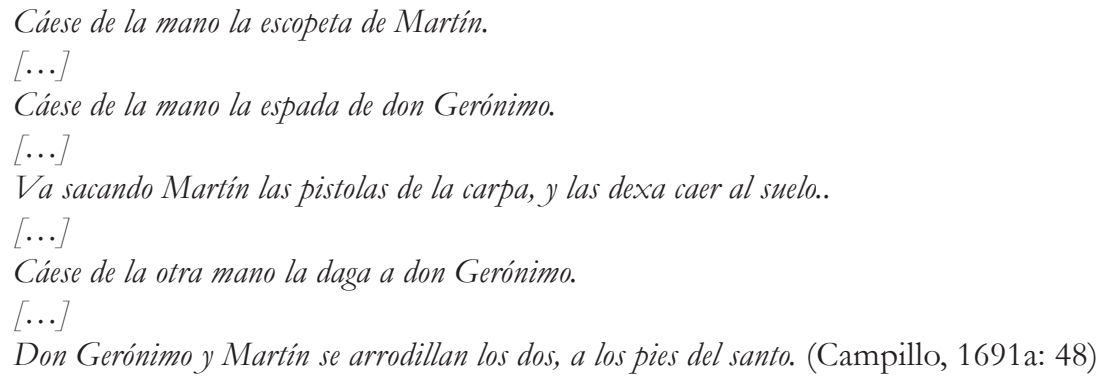

Así, el demonio asume su derrota, de nuevo, e inicia su retirada, acompañada de otro efecto escenográfico:

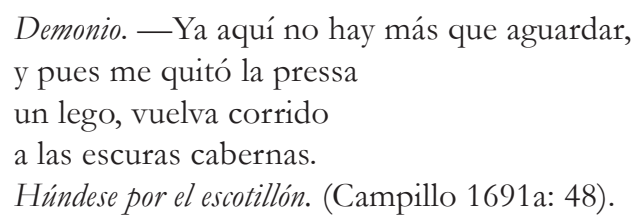

La proximidad del final, acelera el anuncio de la marcha de este mundo por parte de san Pascual. Nuevamente, será Aparicio, compañero constante del santo durante toda la obra, el elegido para comunicar la situación al espectador:

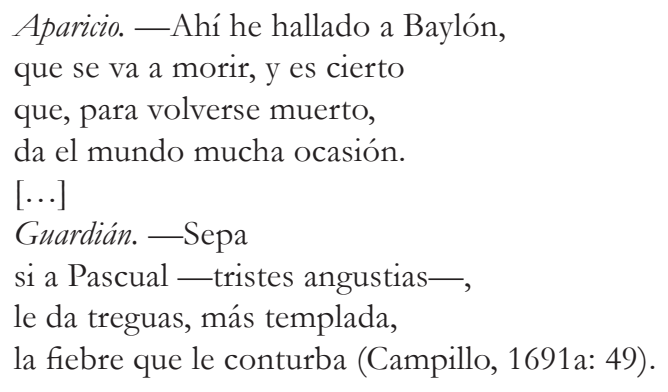

Aparicio, convertido en fiel «escudero» del santo, describe los últimos momentos de Pascual. En esos instantes, Campillo, que prácticamente no había utilizado las posibilidades expresivas de los instrumentos musicales como conjunto, hace uso de estos sobre la escena, con el objetivo de conseguir llamar la atención en lo que sucede. Un recurso, el musical, que en estos contextos es descrito en más de una ocasión (Sirera 1991) a la hora de analizar las técnicas escenográficas utilizadas en el entorno de las comedias de santos: 
Tocan chirimías y corren una cortina, por donde mirava Aparicio; y al mismo tiempo buela, de adentro, un carro rodeado de rayos de fuego. Y en él, como una alma vestida de blanco que buela por el ayre arriba, y dentro se ve, en un féretro, el santo con luzes (Campillo, 1691a: 50).

Todo esto, porque esta muerte, o la de cualquiera de los personajes protagonistas de este subgénero teatral, aunque pudiera resultar contradictorio debido a la denominación, no presenta el dramatismo trágico que supone en otro tipo de creaciones del género. En este caso, nos encontramos ante todo lo contrario: la expiración será lo que refuerce la figura de la santidad, la que comunique a san Pascual con Dios, la que ayude a alcanzar el objetivo final (Cazés 2015):

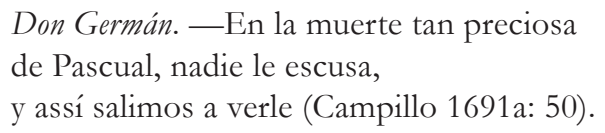

El final también es utilizado para adaptar uno de los milagros con más tradición popular: el que nos señala que sus ojos se abrieron durante su misa de réquiem (Salmerón, 1858). Los personajes no quedan ajenos a este hecho:

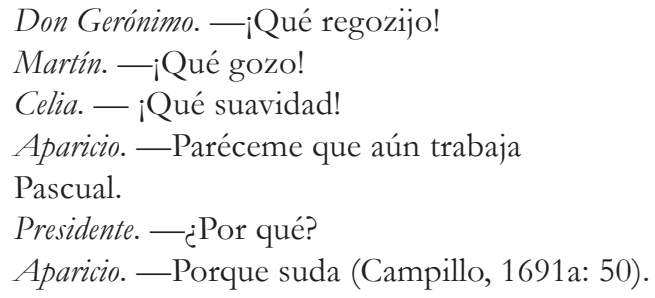

Aunque Campillo, para su gusto, y probablemente el del público, deja el «último milagro»al capricho de su pluma y de su particular forma de pensar. De esta forma, don Germán cede a sus pretensiones iniciales y le pide la mano a Celia: «Todo se debe a san Pascual» (Campillo 1691a: 50), nos hará saber el noble. Mientras, Martín y Vicenta deciden consagrar el resto de sus vidas a la institución eclesiástica, terminando la obra con el tradicional ruego por parte del autor, hacia el público asistente:

\footnotetext{
Y aquí concluye el poeta; y será vitoria suya, si tan prudente auditorio, los yerros dissimula.
} 


\section{Conclusión}

Con la publicación de esta particular comedia, Ginés Campillo ve cumplidos una serie de objetivos ligados a su particular personalidad. No debemos olvidar que, durante 1691, en la calle podemos encontrar ejemplares impresos que recogen parte de su creación lírica, narrativa y dramática: esta última como consecuencia de querer continuar con un género de plena tradición en los clásicos auriseculares a los que el escritor pudo acceder, y con el se sentía, debido a su condición eclesiástica, plenamente identificado.

Con esta creación, Campillo, al menos en la parte teórica, cumple con todos los requisitos exigidos para la construcción de una comedia de santos. Ginés Campillo la adecúa a un marco con el que se encontraba familiarizado, sirviendo a la función propagandística, de la que era tan defensor. La variedad de personajes, la estructura interna, el mensaje transmitido, junto a los temas tratados, la convierten en un claro ejemplo estructural del género; creación a la que añade sus principales obsesiones y conceptos, como es el de su particular idea y visión de la victoria final.

El espíritu que domina la obra, unido al desfile de personajes y a la trama argumental, no se encuentra muy lejano al que observamos en su novela Gustos y disgustos del Lentiscar de Cartagena (1691b). Diversas enseñanzas son las que Campillo quiere proyectar sobre el público o lector, todas ellas próximas a su personal didáctica. Sus obsesiones e intereses aparecerán manifestados en cada una de las escenas que conforman la pieza teatral, acompañadas siempre, y también de la manera tradicional de la época, de su concepción escenográfica en las diferentes situaciones que describe. 
Ramón Doménech Villa. El mejor pastor descalzo, san Pascual Baylón o la incursión teatral de Ginés Campillo de Bayle

\section{Bibliografía}

Alonso, D. (1972) En torno a Lope. Madrid, Gredos.

Aparicio Maydeu, J. “A propósito de la comedia hagiográfica barroca”. En García Martín, M. (ed.) Estado actual de los estudios sobre el Siglo de Oro. Actas del II Congreso Internacional de Hispanistas del Siglo de Oro. Salamanca, Ediciones Universidad de Salamanca (2 vol.), pp. 141-151.

Arellano, I. \& Mata, C. (2011) Vida y obra de Lope de Vega. Madrid, Bibliotheca homolegens.

AA. VV. (2005) Gran Espasa Universal: Enciclopedia Multimedia [DVD]. Barcelona, Espasa.

Arellano, I. (1995) Historia del teatro español del siglo XVII. Madrid, Cátedra.

Barrera y Leyrado de la, C. A. (1860) Catálogo bibliográfico y biográfico del teatro antiguo español, desde sus orígenes hasta mediados del siglo XVIII. Madrid, Imprenta y estereotipia de M. Rivadeneyra.

Calatayud Baya, J. (1977) Diccionario abreviado de personajes alicantinos. Alicante, Obra social y cultural de la Caja de Ahorros Provincial, pp. 52-53. ISBN 978-84-7231-363-7.

Campillo de Bayle, G. (1689) Gustos y disgustos del Lentiscar de Cartagena. Valencia, Imprenta de Francisco Mestre.

- (1691a) El mejor pastor descalio, san Pascual Baylón. Valencia: Imprenta de Vicente Cabrera.

- (1691b) Gustos y disgustos del Lentiscar de Cartagena. Valencia: Imprenta de Francisco Mestre.

Cazés Gryj, J.D. (2015) "La comedia de santos y el teatro en el Siglo de Oro”. Atlanta [en línea], 3, pp. 37-70. [Consulta: 11 de julio de 2016].

Disponible en: http://revistaatalanta.com/index.php/ARLB/index.

Cejador y Frauca, J. (1916) Historia de la Lengua y Literatura Castellana (Vol. V). Madrid, Tipografía de la Revista de archivos, bibliotecas y museos, p. 289.

Corés, J. L. (1693) Demonstraciones festivas, con que la noble, antigua, y siempre leal Villa de Almansa celebró la canonización de su especial patrono y abogado san Pascual Baylón. Madrid, Imprenta Real, Mateo de los Llanos.

Courdec, C. (2008) "Sobre el género y la intriga secundaria en algunas comedias de santos de Lope de Vega". En Pedraza, F. / García, A. (coords.). La comedia de santos. Coloquio internacional. Cuenca, Ediciones de la Universidad de Castilla-La Mancha, pp. 65-84.

Ferrer Valls, T. (1999) "Producción municipal, fiestas y comedia de santos: la canonización de san Luis Bertrán en Valencia (1608)". En Canet, J. L. (coord.) Teatro y prácticas escénicas. Volumen II: La Comedia. London, Tamesis Book Limited / Institución Alfonso el Magnánimo (2 vol.), pp. 156-186.

Galduf Blasco, V. (1961) Luis Beltrán, el santo de los inocentes. Barcelona, Editorial Científico-Médica. 
Ramón Doménech Villa. El mejor pastor descalzo, san Pascual Baylón o la incursión teatral de Ginés Campillo de Bayle

Grazia Profeti, M. (2008) "La comedia de santos entre encargos, teatro comercial, teatro literario". En Pedraza F. / García A. (coords.) La comedia de santos. Coloquio internacional. Cuenca, Ediciones de la Universidad de Castilla-La Mancha, pp. 233-253.

Herzig, C. (2008) “Crítica a las comedias de santos y problemática de la recepción en el «Buen celo» (1683) del padre jesuita Pedro Fomperosa y Quintana". En Pedraza F. / García A. (coords.) La comedia de santos. Coloquio internacional. Cuenca, Ediciones de la Universidad de Castilla-La Mancha, pp. 53-64.

Ibarra Ruiz, P. (1895) Historia de Elche. Alicante, Establecimiento tipográfico de Vicente Botella, p. 311.

Lope de Vega, F. (2002) "El santo negro Rosambuco de la cuidad de Palermo". En Guiliani, L. (coord.) Comedias de Lope de Vega, Parte III. Lleida, Editorial Milenio, pp. 253-296.

- (2006) Arte nuevo de hacer comedias. Madrid, Cátedra.

Martí Grajales, F. (1927) Ensayo de un diccionario biográfico y bibliográfico de los poetas que florecieron en el Reino de Valencia hasta el año 1700. Madrid, Tipografía de la Revista de Archivos, pp. 64-65.

Martínez Berbel, J. A. (2008) "La comedia de santos entre la heterodoxia y la licitud". En Pedraza, F. / García, A. (coords.). La comedia de santos. Coloquio internacional. Cuenca, Ediciones de la Universidad de Castilla-La Mancha, pp. 39-52.

Mas i Usó, P. (1996) Academias y justas literarias en la Valencia barroca. Teoría y práctica de una convención. Kassel, Reichenberger.

Mouyen, J. (1991) "El Corral de la Olivera de Valencia y su público en la segunda mitad del siglo XVII", en Manuel Diago y Teresa Ferrer (eds.) Comedias y comediantes. Estudios sobre el teatro clásico español. Valencia: Universitat de València. Departament de Filologia Espanyola, pp. 407-432.

Ramón González, F. (1687) Sacro Monte Parnaso de las musas católicas de los reinos de España. Valencia, Imprenta de Francisco Mestre.

Salvá y Mallén, P. (1872) Catálogo de la Biblioteca Salvá (T. I). Valencia, Imprenta de Ferrer de Orga.

Simini, D. (1999) "Antonio Fajardo y Acevedo, commediografo paradigmatico della fine di un secolo e di una dinastia". En Fine secolo e scrittura: dal medioevo ai giorni nostri. Atti del XVIII Convegno [AISPI]. Siena, Bulzoni Editore, pp. 115-120.

Simón Díaz, J. Bibliografía de la literatura hispánica (vol.VII). Madrid, Consejo Superior de Investigaciones Científicas (13 vol.), 1967, pp. 356-357.

Sirera Turó, J. L. (1991) "Los santos en sus comedias: hacia una tipología de los protagonistas del teatro hagiográfico". En Diago M. / Ferrer T. (eds.) Comedias y comediantes. Estudios sobre el teatro clásico español. Valencia: Universitat de València. Departament de Filologia Espanyola, pp. 55-76.

- (1995) Historia de la literatura valenciana. Valencia, Institución Alfonso el Magnánimo, pp. 295-297.

- (1999) "Las «comedias de santos» en los autores valencianos. Notas para su estudio". En Canet, J. L. (coord.) Teatro y prácticas escénicas. Volumen II: La Comedia. London, Tamesis Book Limited / Institución Alfonso el Magnánimo (2 vol.), pp. 187-230. 
Ramón Doménech Villa. El mejor pastor descalzo, san Pascual Baylón o la incursión teatral de Ginés Campillo de Bayle

Snavely, R. (1927) A study of «Gustos y disgustos del Lentiscar de Cartagena» of Ginés Campillo de Bayle. Columbia University.

Teulade, A. (2008) "Santidad y teatralidad: el santo como paradoja estética”. En Pedraza, F. / García, A. (coords.). La comedia de santos. Coloquio internacional. Cuenca, Ediciones de la Universidad de Castilla-La Mancha, pp. 21-37.

Vega García-Lenguos, G. (2008) "Sobre la trayectoria editorial de las comedias de santos". En Pedraza F. / García A. (coords.) La comedia de santos. Coloquio internacional.. Cuenca, Ediciones de la Universidad de Castilla-La Mancha, pp. 21-37. 